\title{
Penerapan Algoritma Klasifikasi dengan Fitur Seleksi Weight By Information Gain pada Pemodelan Prediksi Kelulusan Mahasiswa
}

\author{
Avira Budianita ${ }^{1 *}$, Fandy Indra Pratama ${ }^{2}$ \\ ${ }^{1}$ Program Studi Ilmu Komputer, Universitas Muhammadiyah Kudus \\ ${ }^{2}$ Program Studi Teknik Informatika, Universitas Wahid Hasyim \\ ${ }^{1} \mathrm{Jln}$. Ganesha 1 Purwosari, Kabupaten Kudus, 59316, Indonesia \\ ${ }^{2} J$ In. Menoreh Tengah X / 22 Sampangan Gajahmungkur, Kota Semarang, 50232, Indonesia \\ E-mail: avirabudianita@umkudus.ac.id ${ }^{\mathbf{1}}$, fandy @ unwahas.ac.id ${ }^{2}$
}

\section{Info Naskah:}

Naskah masuk: 13 Juni 2020

Direvisi: 29 Juli 2020

Diterima: 6 Agustus 2020

\begin{abstract}
Abstrak
Permasalahan yang dihadapi institusi perguruan tinggi adalah tidak tepatnya kelulusan mahasiswa. Hal tersebut yang menjadi tugas institusi perguruan tinggi terutama program studi dalam memantau akademik mahasiswanya. Dewasa ini, banyak sekali metode atau cara untuk menyelesaikan berbagai permasalahan teknologi informasi salah satunya dengan penggunaan machine learning pada data mining. Penelitian ini menggunakan algoritma Naive Bayes, Linear Regression, dan MultiLayer Perceptron serta fitur seleksi Weight by Information Gain untuk optimalisasi akurasi dalam memprediksi waktu kelulusan mahasiswa. Hasil pengolahan dataset dengan atribut jalur pendaftaran, asal sekolah, asal kota, dan Indeks Prestasi semester 1 sampai 4 pada RapidMiner dengan menerapkan ketiga algoritma beserta fitur seleksi tersebut menghasilkan akurasi yang tergolong baik. Naive Bayes menghasilkan akurasi sebesar $81.66 \%$ dengan waktu eksekusi 1,16 detik, Linear Regression sebesar $80.70 \%$ dalam 2,44 detik dan MultiLayer Perceptron sebesar 82.16\% dalam 1 jam 57 menit.
\end{abstract}

\section{Keywords:}

Linier Regression;

MultiLayer Perceptron;

Naive Bayes;

Time of Graduation;

Weight by Information Gain.

\begin{abstract}
The problem faced by institutions of higher education is not exactly of graduation. It is the task of institution of higher education, especially courses in the students academic monitoring. Today, there are many methods or ways to solve various problems of information technology either by machine learning at data mining. This study uses Naive Bayes. Linear Regression, dan Multi Layer Perceptron algorithm also Weight by Information Gain as Features Selection to optimize accuracy in predicting the time of students graduation. The dataset processing with certain attributes including registration line, origin school, origin city, and the semester grade point 1 to 4 in RapidMiner by implementing the three algorithms along with the selection feature produces relatively good accuracy. Naive Bayes produces an accuracy of $81.66 \%$ with an execution time of 1.16 seconds, Linear Regression of $80.70 \%$ in 2.44 seconds and Multi Layer Perceptron of $82.16 \%$ in 1 hour 57 minutes.
\end{abstract}




\section{Pendahuluan}

Tingkat kelulusan mahasiswa pada suatu perguruan tinggi menjadi tolak ukur keberhasilan dari perguruan tinggi itu sendiri. Pada Peraturan Menteri Pendidikan dan Kebudayaan Republik Indonesia (Permendikbud), studi S1 harus menempuh program belajar paling sedikit 144 sks atau menyelesaikan pendidikannya selama 4 tahun [1]. Tingkat kelulusan mahasiswa program studi XYZ pada suatu universitas berada di bawah standar yang telah ditetapkan oleh BAN-PT yaitu sebesar 50\% dari mahasiswa yang mendaftar. Hal ini menjadi tugas tersendiri untuk program studi dalam mengevaluasi kinerja akademiknya guna mencapai standar lulusan mahasiswa yang telah ditetapkan oleh BAN-PT.

Penelitian-penelitian terdahulu saat ini terdapat beberapa yang mencoba untuk membandingkan beberapa lagoritma [3]. Pada penelitian Xhemali dkk [2], peneliti membandingkan 3 algoritma antara lain Naive Bayes, Decision Tree, dan Neural Network untuk klasifikasi web. Dari penelitian tersebut Naive Bayes menghasilkan akurasi yang lebih unggul daripada 2 algoritma lainnya. Sehingga Xhemali dkk menyimpulkan bahwa Algoritma Naive Bayes bekerja baik dalam melakukan proses klasifikasi dengan dataset web dibanding dengan algoritma lainnya pada penelitiannya.

Penelitian Arsad dkk dua tahun berturut-turut pada tahun 2013 dan 2014 [4][5][6] membandingkan algoritma Linear Regression dan Neural Network untuk memprediksi performa mahasiwa teknik pada fakultas Electrical Engineering, Universiti Teknologi MARA (UiTM) Malaysia. Pada penelitian ini, Arsad et al menggunakan IPK (Indeks Prestasi Kumulatif) mahasiswa sebagai label atau output pada datasetnya, sedangkan atribut yang digunakan sebagai variabel prediktor input adalah nilai mata kuliah pada semester-semester awal dan model yang dihasilkan adalah berbentuk MSE (Mean Square Error). Hasil penelitian dari kedua model menunjukkan korelasi yang kuat antara hasil yang mendasar untuk mata pelajaran inti di semester satu atau semester tiga dengan IPK akhir.

MultiLayer Perceptron digunakan oleh Houari dkk [7] pada penelitiannya yang dikembangkan dengan algoritma training Levenberg-Marquardt untuk prediksi suhu udara di wilayah Meknes di Maroko. Atribut yang digunakan pada penelitian Houri et al ini adalah tekanan atmosfer (Pr), kelembaban $(\mathrm{H})$, visibility (Vis), kecepatan angin (V), titik embun $(\mathrm{Tr})$ dan curah hujan $(\mathrm{P})$. Dataset yang digunakan berisi sejarah meteorologi parameter scovering 3288 hari, dari tahun 2004 sampai 2012. MLP pada penelitian ini digunakan untuk mendekati hubungan antara parameter ini dengan Minimum Square Error. Untuk prediksi suhu udara yang lebih baik, Houari dkk mengembangkan model neural stokastik. Mean Square Error (MSE) dan koefisien korelasi (R) digunakan untuk mengevaluasi kinerja model yang dikembangkan. Studi indikator statistik ini menunjukkan bahwa prediksi suhu udara yang kuat dengan algoritma Levenberg-Marquard.

Beberapa penelitian juga menggunakan fitur seleksi untuk meningkatkan dan mengoptimalisasi hasil akurasi dari algoritma klasifikasi yang antara lain yaitu Weight by Information Gain, yang mana fitur seleksi tersebut berfungsi untuk memberikan nilai bobot pada setiap atribut yang relevan untuk proses prediksi.

Berdasarkan penelitian terkait tersebut, peneliti membandingkan keakuratan tiga algoritma klasifikasi ketika dilakukan seleksi Weight by Information Gain. Tiga algoritma tersebut adalah Naive Bayes, Linier Regression dan Multi Layer Perceptron yang mana algoritma tersebut memiliki keuanggulan pada kasus-kasus tertentu. Serta penggunaan variable Indeks Prestasi Semester (IPS) yang telah ditempuh hingga semester IV, jenis kelamin, kota lahir, asal kota, dan asal sekolah [8][9], dapat dijadikan sebagai prediktor untuk permasalahan prediksi kelulusan mahasiswa dalam penelitian ini.

Sehingga hasil dari penelitian ini yang membandingkan algoritma Naive Bayes, Linier Regression dan Multi Layer Perceptron ketika data dilakukan seleksi Weight by Information Gain menghasilkan kesimpulan baru yang dapat digunakan sebagai dasar membangun sistem prediksi yang optimal.

\section{Metode Penelitian}

Pada penelitian ini menggunakan dataset salah satu universitas di indonesia. Atribut dari dataset tersebut antara lain perlu dilakukan preprocessing karena terdapat data yang kiranya tidak digunakan. Berikut ini langkah-langkah dalam preprocessing yang dilakukan pada penelitian ini:

1) Penghapusan Record

Beberapa record dari data yang diperoleh akan dihapus pada proses ini yaitu data mahasiswa transfer dan pindahan serta data mahasiswa yang aktif, mangkir, ataupun cuti.

\section{2) Penghapusan Atribut}

Pada pemrosesan mining, atribut yang tidak memiliki pengaruh atau tidak digunakan harus dihapus seperti atribut NIM dan status akademik dan atribut yang digunakan pada proses menggunakan RapidMiner adalah jalur pendaftaran, asal sekolah, asal kota, ips1, ips2, ips3, dan ips4.

\section{3) Pemberian Label}

Pemberian label "1" untuk mahasiswa yang lulus tepat waktu yaitu yang menempuh pendidikan selama 3,5 tahun dan 4 tahun. Sedangkan label "2" untuk mahasiswa yang lulus tidak tepat waktu atau yang menempuh pendidikan lebih dari 4 tahun.

\section{4) Inisialisasi}

Proses inisialisasi ini dilakukan untuk memberikan inisial pada atribut asal sekolah dan asal kota. Asal sekolah diinisialisasi menjadi 2 kategori yaitu SMA dan SMK. Sedangkan asal kota akan diinisialisasi menjadi 2 kategori juga yaitu DALAM_KOTA dan LUAR_KOTA.

Selanjutnya data tersebut dilakukan seleksi atribut kembali dengan menggunakan Weight by Information Gain sebelum dilakukan klasifikasi oleh algoritma Naive Bayes, Linier Regression dan Multi Layer Perceptron 


\subsection{Weight by Information Gain}

Weight by Information Gain merupakan salah satu algoritma yang mempunyai fungsi untuk menghitung relevansi atribut terhadap variabel target atau atribut label berdasarkan rasio gain informasi dan memberikan bobot yang sesuai pada atribut tersebut. Semakin tinggi nilai berat atribut, semakin atribut tersebut dianggap relevan. Bobot dari setiap atribut yang dianggap relevan atau memiliki mempengaruhi terhadap atribut label adalah kisaran 01[14][15], sehingga dihasilkan atribut yang digunakan pada penelitian ini yaitu pada Tabel 1. Pada Gambar 1 adalah contoh dataset yang digunakan pada penelitian ini.

\begin{tabular}{|c|c|c|c|c|}
\hline NO & Atribut & $\begin{array}{l}\text { Tipe } \\
\text { Data }\end{array}$ & Kategori & Keterangan \\
\hline 1. & $\begin{array}{c}\text { Jalur } \\
\text { Pendaf- } \\
\text { taran }\end{array}$ & Integer & $\begin{array}{l}\text { Reguler }=1 \\
\text { Khusus }=2 \\
\text { PMDK = } 3 \\
\text { Beasiswa } \\
\text { Unggulan = 4 }\end{array}$ & $\begin{array}{l}\text { Jalur pendaftaran } \\
\text { yang ditempuh } \\
\text { mahasiswa pada } \\
\text { saat pertama kali } \\
\text { masuk } \\
\text { universitas. }\end{array}$ \\
\hline 2. & $\begin{array}{l}\text { Asal } \\
\text { SLTA }\end{array}$ & Integer & $\begin{array}{l}\mathrm{SMA}=1 \\
\mathrm{SMK}=2\end{array}$ & $\begin{array}{l}\text { Asal sekolah } \\
\text { mahasiswa }\end{array}$ \\
\hline 3. & $\begin{array}{l}\text { Kota } \\
\text { Asal }\end{array}$ & Integer & $\begin{array}{c}\text { Dalam Kota }=1 \\
\text { Luar Kota }=2\end{array}$ & $\begin{array}{l}\text { Asal kota } \\
\text { mahasiswa }\end{array}$ \\
\hline 4. & IPS1 & Numeric & $0-4$ & $\begin{array}{l}\text { IPS mahasiswa } \\
\text { pada semester } 1\end{array}$ \\
\hline 5. & IPS2 & Numeric & $0-4$ & $\begin{array}{l}\text { IPS mahasiswa } \\
\text { pada semester } 2\end{array}$ \\
\hline 6. & IPS3 & Numeric & $0-4$ & $\begin{array}{l}\text { IPS mahasiswa } \\
\text { pada semester } 3\end{array}$ \\
\hline 7. & IPS4 & Numeric & $0-4$ & $\begin{array}{l}\text { IPS mahasiswa } \\
\text { pada semester } 4\end{array}$ \\
\hline
\end{tabular}

\begin{tabular}{|c|c|c|c|c|c|c|c|c|c|c|}
\hline 4 & $\bar{A}$ & $\bar{B}$ & $\mathrm{c}$ & & $\bar{D}$ & $\bar{E}$ & $\bar{F}$ & $\bar{G}$ & $\mathrm{H}$ & 1 \\
\hline 1 & jalur_daftar & asal_SLTA & kota_asal & & ips1 & ips2 & ips3 & ips4 & status & \\
\hline 2 & 1 & 1 & & 2 & 2,68 & 2,30 & 3,00 & 3,00 & 1 & \\
\hline 3 & 1 & 1 & & 2 & 3,20 & 3,13 & 3,13 & 2,75 & 1 & \\
\hline 4 & 1 & 1 & & 2 & 2,50 & 3,30 & 3,83 & 3,57 & 1 & \\
\hline 5 & 1 & 1 & & & 3,65 & 3,43 & 3,39 & 3,61 & 1 & \\
\hline 6 & 1 & 1 & & & 3,45 & 3,48 & 4,00 & 3,87 & 1 & \\
\hline 7 & 1 & 1 & & i & 2,25 & 3,14 & 3,39 & 3,10 & 1 & \\
\hline 8 & 1 & 1 & & 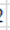 & 3,05 & 3,58 & 3,83 & 3,82 & 1 & \\
\hline 9 & 1 & 2 & & & 2,20 & 3,81 & 3,62 & 3,74 & 1 & \\
\hline 10 & 1 & 1 & & $i$ & 2,95 & 3,29 & 3,91 & 3,91 & 1 & \\
\hline 11 & 1 & 1 & & 2 & 2,40 & 2,57 & 3,09 & 2,62 & 1 & \\
\hline 12 & 1 & 2 & & 1 & 2,65 & 3,00 & 2,89 & 3,48 & 1 & \\
\hline 13 & 1 & 1 & & & 3,25 & 3.21 & 3,10 & 3,05 & 1 & \\
\hline 14 & 1 & 1 & & 2 & 2,95 & 3,24 & 3,29 & 3,24 & 1 & \\
\hline 15 & 1 & 1 & & & 3,05 & 3,00 & 3,71 & 3,17 & 1 & \\
\hline
\end{tabular}

Gambar 1. Contoh Dataset

Selanjutnya dari data tersebut dilakukan perbandingan antara klasifikasi menggunakan algoritma Naive Bayes, Linear Regression, dan Multi Layer Perceptron (MLP) berdasarkan Weight by Information Gain sebagai pembobot atribut.

\subsection{Naive Bayes Classifier}

Naive Bayes Classifier (NBC) merupakan salah satu algoritma data mining yang menerapkan teorema Bayes dalam proses klasifikasi. Naive Bayes Classifier sendiri memiliki definisi pengklasifikasian dengan teknik probabilitas dan statistik untuk memprediksi kejadian di masa depan berdasarkan kejadian yang sudah ada sebelumnya [10][11]. Persamaan Teorema Bayes dan penjelasannya seperti pada persamaan 1 dan Tabel 2.

$$
P(H \mid X)=\frac{P(X \mid H) \cdot P(H)}{P(X)}
$$

Tabel 2. Keterangan Persamaan Teorema Bayes

\begin{tabular}{ll}
\hline$X$ & Data dengan class yang belum diketahui \\
\hline$H$ & Hipotesis data $X$ yang merupakan suatu class \\
& yang spesifik \\
$P(H \mid X)$ & Probabilitas $H$ berdasarkan data $X$ (posteriori) \\
$P(X \mid H)$ & Probabilitas $X$ berdasarkan kondisi $H$ \\
$P(H)$ & Probabilitas $H$ (prior) \\
$P(X)$ & Probablitas $X$ \\
\hline
\end{tabular}

\subsection{Linear Regression}

Linear Regression merupakan algoritma yang digunakan ketika akan memprediksi nilai dari suatu variabel berdasarkan nilai variabel yang lain. Bila ada lebih dari satu variabel input, Linear Regression akan menjadi Multiple Linear Regression atau Multiple Regression [4]. Persamaan Linear Regression seperti pada persamaan 1, serta penjelasannya pada tabel 3 .

$$
Y=a+b X
$$

Tabel 3. Keterangan Persamaan Linear Regression

\begin{tabular}{ll}
\hline$Y$ & Variabel Response atau Variabel Akibat (Dependent) \\
\hline$a$ & Konstanta \\
$b$ & $\begin{array}{l}\text { koefisien regresi (kemiringan); besaran Response yang } \\
\text { ditimbulkan oleh Predictor. }\end{array}$ \\
$X$ & $\begin{array}{l}\text { Variabel Predictor atau Variabel Faktor Penyebab } \\
\text { (Independent) }\end{array}$ \\
\hline
\end{tabular}

\subsection{Multi Layer Perceptron}

Multi Layer Perceptron (MLP) adalah suatu model feed-forward jaringan saraf tiruan yang memetakan set input data ke satu set output yang sesuai. MLP terdiri dari beberapa lapisan node dalam sebuah grafik yang diarahkan, dengan masing-masing lapisan sepenuhnya terhubung ke lapisan berikutnya. Kecuali untuk node input, setiap node adalah neuron (atau elemen pengolahan) dengan fungsi aktivasi nonlinier.

MLP menggunakan back propagation untuk pelatihan jaringan. Kelas jaringan ini terdiri dari beberapa lapisan unit komputasi, biasanya berhubungan dengan cara feedforward. Dalam banyak aplikasi unit jaringan ini menerapkan fungsi sigmoid sebagai fungsi aktivasi [12][13]. 


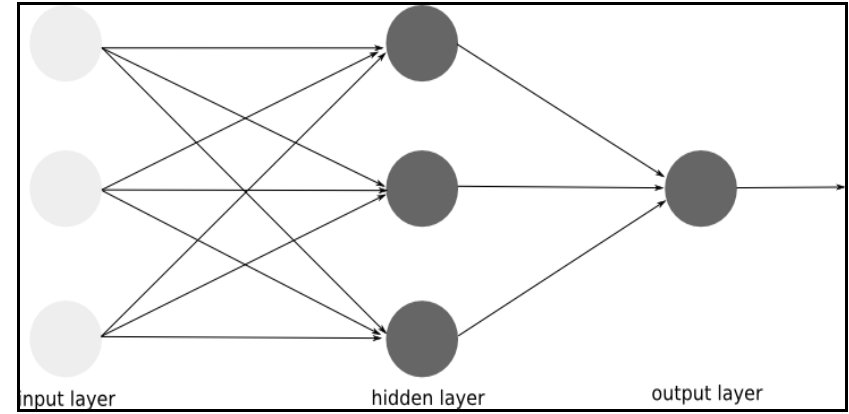

Gambar 2. Jaringan Multi Layer Perceptron

\section{Hasil dan Pembahasan}

\subsection{Implementasi Algoritma Klasifikasi}

Implementasi algoritma dilakukan dengan menguji dataset mahasiswa menggunakan tools RapidMiner dengan 10 fold number of validation dan linear sampling untuk tipe samplingnya. Pada Gambar 3 menunjukkan dataset mahasiswa diuji menggunakan $X$-Validation pada RapidMiner. Pada Gambar 4 menunjukkan klasifikasi dengan menggunakan algoritma Naive Bayes pada $X$ Validation, serta Gambar 5 menunjukkan klasifikasi dengan menggunakan algoritma Linear Regression pada $X$ Validation.

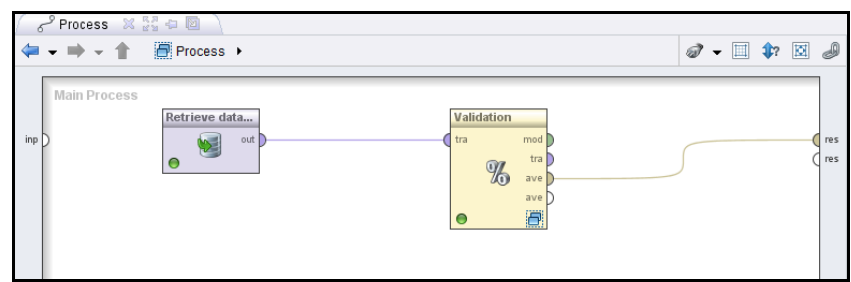

Gambar 3. Implementasi Algoritma

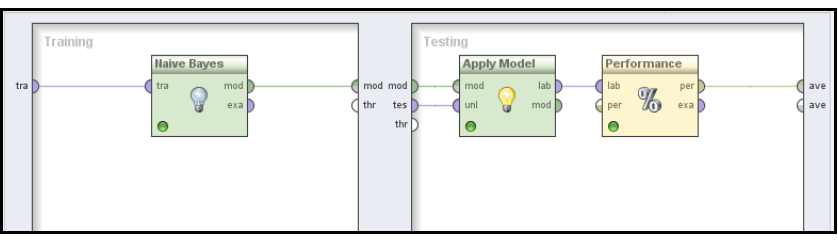

Gambar 4. X-Validation Naive Bayes

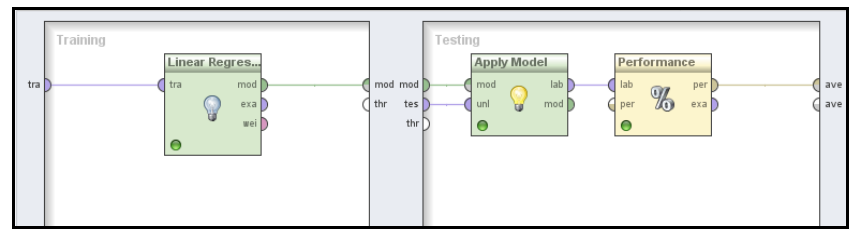

Gambar 5. X-Validation Linear Regression

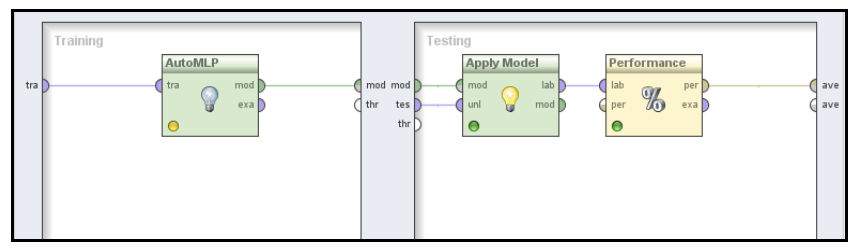

Gambar 6. X-Validation Multi Layer Perceptron
Pada Gambar 6 menunjukkan klasifikasi dengan menggunakan algoritma Multi Layer Perceptron pada $X$ Validation. Validasi dengan $X$-Validation menggunakan RapidMiner menghasilkan tingkat akurasi dari ketiga algoritma tersebut dan tabel confusion matrix.

Tabel 4. Confusion Matrix [16]

\begin{tabular}{|c|c|c|}
\hline \multirow{2}{*}{ Classification } & \multicolumn{2}{|c|}{ Predicted Class } \\
\hline & Class $=$ Yes & Class $=\mathrm{No}$ \\
\hline \multirow{2}{*}{ Class $=$ Yes } & $A$ & $B$ \\
\hline & (True Positive-TP) & (False Negative-FN) \\
\hline \multirow{2}{*}{ Class $=N o$} & $C$ & $D$ \\
\hline & (False Positive-FP) & (True Negative-TN) \\
\hline
\end{tabular}

Keterangan dari tabel confusion matrix tersebut adalah:

a. A (True Positive-TP) : proporsi benar dalam dataset kategori benar.

b. B (False Negative-FN) : proporsi salah dalam dataset kategori salah.

c. C (False Positive-FP) : proporsi salah dalam dataset kategori benar.

d. D (True Negative-TN) : proporsi benar dalam dataset kategori salah.

Dari implementasi validasi algoritma Naive Bayes pada RapidMiner menggunakan X-Validation didapatkan hasil seperti pada Gambar 7. Perhitungan accuracy, error rate, precision, recall, dan $f$-measure berdasarkan confusion matrix algoritma Naive Bayes yang didapatkan dari proses validasi.

\begin{tabular}{|c|c|c|c|}
\hline Accuracy & $\frac{T P+T N}{T P+T N+F P+F N}=$ & $\frac{232+266}{232+266+63+61}=$ & 0.8007 \\
\hline Error Rate & $\frac{F P+F N}{T P+T N+F P+F N}=$ & $\frac{63+61}{232+266+63+61}=$ & 0.1993 \\
\hline Precision & $\frac{T P}{T P+F P}=$ & $\frac{232}{232+63}=$ & 0.7864 \\
\hline Recall & $\frac{T P}{T P+F N}=$ & $\frac{232}{232+51}=$ & 0.8198 \\
\hline F-Measure & $\frac{2(P R E C I S I O N * R E C A L L)}{P R E C I S I O N+R E C A L L}=$ & $\frac{2(0.7864 * 0.8189)}{0.7864+0.8189}=$ & 0.8023 \\
\hline
\end{tabular}

Dari implementasi validasi algoritma Linear Regression menggunakan X-Validation didapatkan hasil seperti Gambar 8.

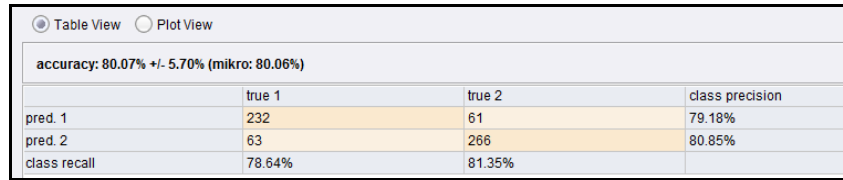

Gambar 7. Akurasi \& Confusion Matrix Naive Bayes

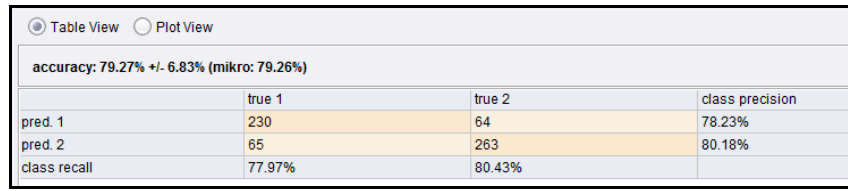

Gambar 8. Akurasi \& Confusion Matrix Linear Regression 
Berikut adalah perhitungan accuracy, error rate, precision, recall, dan $f$-measure berdasarkan confusion matrix algoritma Linear Regression yang didapatkan dari proses validasi.

\begin{tabular}{|c|c|c|c|}
\hline Accuracy & $\frac{T P+T N}{T P+T N+F P+F N}=$ & $\frac{230+263}{230+263+65+64}=$ & 0.7927 \\
\hline Error Rate & $\frac{F P+F N}{T P+T N+F P+F N}=$ & $\frac{65+64}{230+263+65+64}=$ & 0.2074 \\
\hline Precision & $\frac{T P}{T P+F P}=$ & $\frac{230}{230+65}=$ & 0.7997 \\
\hline Recall & $\frac{T P}{T P+F N}=$ & $\frac{230}{230+64}=$ & 0.7823 \\
\hline F-Measure & $\frac{2(\text { PRECISION } * \text { RECALL })}{\text { PRECISION }+ \text { RECALL }}$ & $\frac{2(0.7997 * 0.7823)}{0.7997+0.7823}=$ & 0.7909 \\
\hline
\end{tabular}

Dari implementasi validasi algoritma Multi Layer Perceptron menggunakan $X$-Validation didapatkan hasil pada Gambar 9.

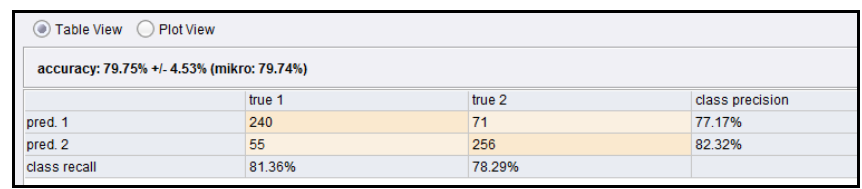

Gambar 9. Akurasi \& Confusion Matrix Multi Layer Perceptron

Berikut adalah perhitungan accuracy, error rate, precision, recall, dan f-measure berdasarkan confusion matrix algoritma Multi Layer Perceptron yang didapatkan dari proses validasi.

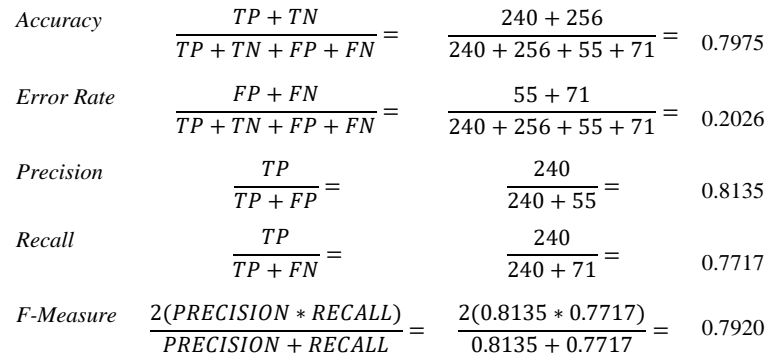

Hasil akurasi yang didapat pada implementasi ketiga algoritma tersebut menunjukkan hasil akurasi yang berbeda, hasil akurasi ditunjukkan pada Tabel 5.

Tabel 5. Perbandingan Akurasi \& Waktu Eksekusi Ketiga

\begin{tabular}{lcc}
\multicolumn{3}{c}{ Algoritma } \\
\hline \multicolumn{1}{c}{ Algoritma } & Akurasi & Waktu Eksekusi \\
\hline Naive Bayes & $80.06 \%$ & 0,63 detik \\
Linear Regression & $79.27 \%$ & 0,63 detik \\
Multi Layer Perceptron & $79.75 \%$ & 3 menit 38 detik \\
\hline
\end{tabular}

Tabel 5 menunjukkan hasil akurasi dan waktu eksekusi yang dibutuhkan dalam memproses data mahasiswa untuk prediksi kelulusan mahasiswa dengan 10 fold number of validation dan linear sampling pada validasinya.

\subsection{Implementasi Fitur Seleksi pada Algoritma Klasifikasi}

Implementasi algoritma yang dilakukan pada bagian ini sama dengan implementasi algoritma pada bagian sebelumnya tetapi ditambah dengan implementasi fitur seleksi Weight by Information Gain, telrihat pada Gambar 10. Di dalam operator Optimize Selection ditambahkan operator validasi untuk mengetahui hasil akurasi yang dihasilkan dari implementasi algoritma dan fitur seleksi Weight by Information Gain. Gambar 11 menunjukkan dataset mahasiswa diuji menggunakan $X$-Validation. Kemudian pada operator validasi diisikan algoritma yang akan diketahui hasil akurasinya sama seperti pada implementasi algoritma pada gambar 3. Pada Gambar 12 menunjukkan klasifikasi dengan menggunakan algoritma Naive Bayes + fitur seleksi Weight by Information Gain pada X-Validation. Gambar 13 menunjukkan klasifikasi dengan menggunakan algoritma Linier Regression + fitur seleksi Weight by Information Gain pada $X$-Validation.

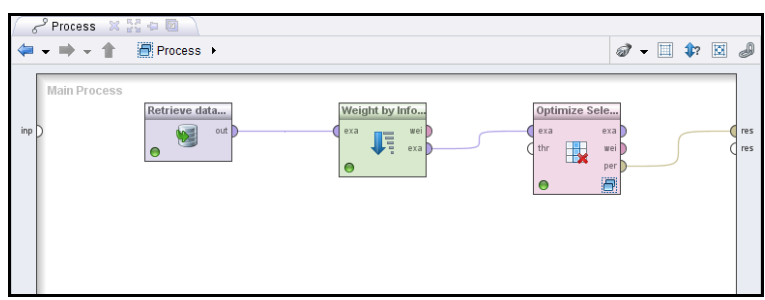

Gambar 10. Implementasi Algoritma + Fitur Seleksi

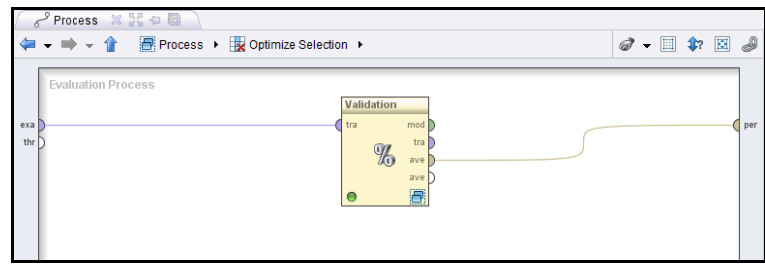

Gambar 11. Operator X-Validation pada Implementasi Algoritma + Fitur Seleksi

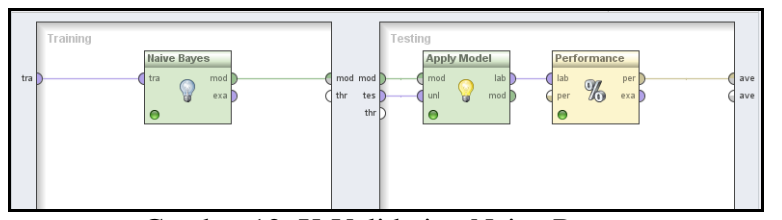

Gambar 12. X-Validation Naive Bayes

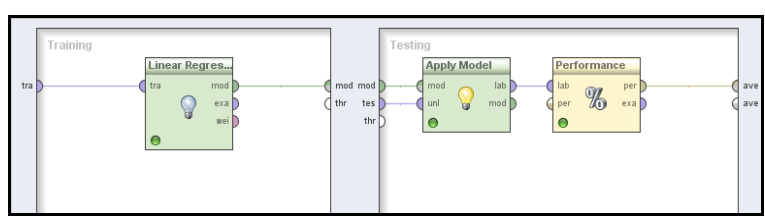

Gambar 13. X-Validation Linear Regression

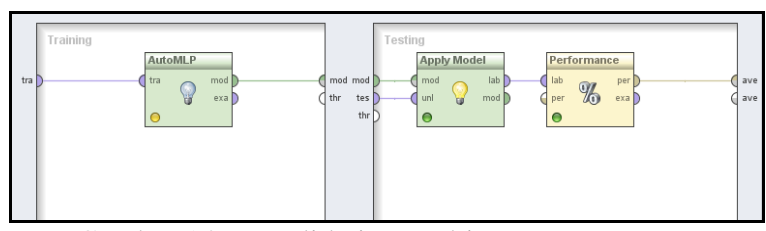

Gambar 14. X-Validation Multi Layer Perceptron 
Pada Gambar 14 menunjukkan klasifikasi dengan menggunakan algoritma Multi Layer Perceptron + fitur seleksi Weight by Information Gain pada X-Validation. Berdasarkan validasi dengan $X$-Validation menghasilkan tingkat akurasi dari ketiga algoritma ditambah dengan fitur seleksi Weight by Information Gain tersebut dan tabel confusion matrixnya.

Dari implementasi validasi algoritma Naive Bayes dengan Weight by Information Gain menggunakan XValidation didapatkan hasil seperti pada Gambar 15.

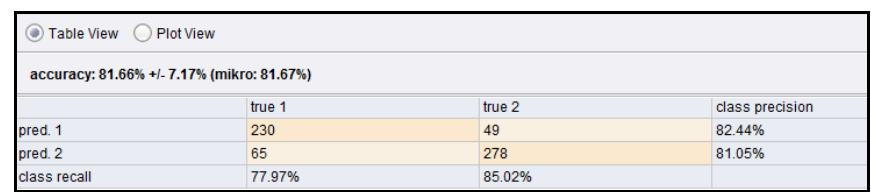

Gambar 15. Akurasi \& Confusion Matrix Naive Bayes

Berikut adalah perhitungan accuracy, error rate, precision, recall, dan $f$-measure berdasarkan confusion matrix algoritma Naive Bayes + Weight by Information Gain.

\begin{tabular}{|c|c|c|c|}
\hline Accuracy & $\frac{T P+T N}{T P+T N+F P+F N}=$ & $\frac{230+278}{230+278+65+49}=$ & 0.8166 \\
\hline Error Rate & $\frac{F P+F N}{T P+T N+F P+F N}=$ & $\frac{65+49}{230+278+65+49}=$ & 0.1833 \\
\hline Precision & $\frac{T P}{T P+F P}=$ & $\frac{230}{230+65}=$ & 0.7797 \\
\hline Recall & $\frac{T P}{T P+F N}=$ & $\frac{230}{230+49}=$ & 0.8244 \\
\hline F-Measure & $\frac{2(\text { PRECISION } * \text { RECALL })}{\text { PRECISION }+ \text { RECALL }}=$ & $\frac{2(0.7797 * 0.8244)}{0.7797+0.8244}=$ & 0.8108 \\
\hline
\end{tabular}

Dari implementasi validasi algoritma Linear Regression dengan Weight by Information Gain menggunakan $X$-Validation didapatkan hasil seperti pada Gambr 16.

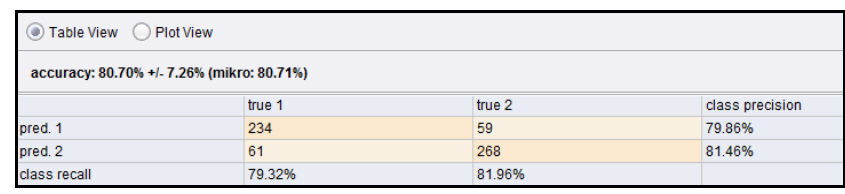

Gambar 16. Akurasi \& Confusion Matrix Linear Regression

Berikut adalah perhitungan accuracy, error rate, precision, recall, dan f-measure berdasarkan confusion matrix algoritma Linear Regression + Weight by Information Gain.

$$
\begin{array}{lccc}
\text { Accuracy } & \frac{T P+T N}{T P+T N+F P+F N}= & \frac{234+268}{234+268+61+59}= & 0.8070 \\
\text { Error Rate } & \frac{F P+F N}{T P+T N+F P+F N}= & \frac{61+59}{234+268+61+59}= & 0.1929 \\
\text { Precision } & \frac{T P}{T P+F P}= & \frac{234}{234+61}= & 0.7932 \\
\text { Recall } & \frac{T P}{T P+F N}= & \frac{234}{230+59}= & 0.7986 \\
\text { F-Measure } & \frac{2(P R E C I S I O N * \text { RECALL })}{P R E C I S I O N+R E C A L L}= & \frac{2(0.7932 * 0.7986)}{0.7932+0.7986}= & 0.7959
\end{array}
$$

Dari implementasi validasi algoritma Multi Layer Perceptron dengan Weight by Information Gain menggunakan $X$-Validation didapatkan hasil seperti pada Gambar 17.

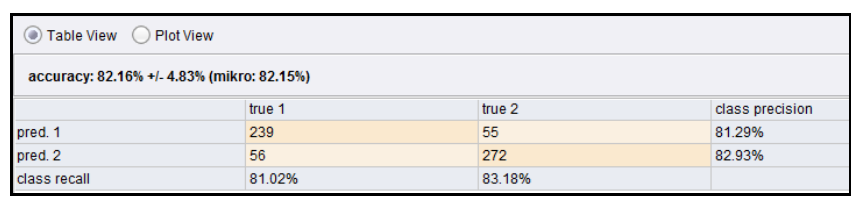

Gambar 17. Akurasi \& Confusion Matrix Multi Layer Perceptron

Berikut adalah perhitungan accuracy, error rate, precision, recall, dan f-measure berdasarkan confusion matrix algoritma Multi Layer Perceptron + Weight by Information Gain.

$$
\begin{aligned}
& \text { Accuracy } \frac{T P+T N}{T P+T N+F P+F N}=\frac{239+272}{239+272+56+55}=0.8216 \\
& \text { Error Rate } \frac{F P+F N}{T P+T N+F P+F N}=\frac{56+55}{239+272+56+55}=0.1785 \\
& \text { Precision } \quad \frac{T P}{T P+F P}=\quad \frac{239}{239+56}=0.8102 \\
& \text { Recall } \quad \frac{T P}{T P+F N}=\quad \frac{239}{239+55}=0.8129 \\
& \text { F-Measure } \quad \frac{2(\text { PRECISION } * \text { RECALL })}{\text { PRECISION }+ \text { RECALL }}=\frac{2(0.8102 * 0.8129)}{0.8102+0.8129}=0.8115
\end{aligned}
$$

Hasil akurasi yang di dapat pada implementasi ketiga algoritma tersebut menunjukkan hasil akurasi yang berbeda, hasil akurasi ditunjukkan pada Tabel 6 . Tabel 6 menunjukkan hasil akurasi dan waktu eksekusi dalam memproses data mahasiswa untuk prediksi kelulusan mahasiswa dengan algoritma Naive Bayes, Linear Regression, Multi Layer Perceptron dengan fitur seleksi Weight by Information Gain.

Tabel 6. Perbandingan Akurasi \& Waktu Eksekusi Ketiga Algoritma + Fitur Seleksi

\begin{tabular}{lcc}
\hline \multicolumn{1}{c}{ Algoritma } & Akurasi & Waktu Eksekusi \\
\hline Naive Bayes & $81.66 \%$ & 1,16 detik \\
Linear Regression & $80.70 \%$ & 2,44 detik \\
Multi Layer & $82.16 \%$ & 1 jam 57 menit \\
Perceptron & & \\
\hline
\end{tabular}

Tabel 7. Perbandingan Akurasi Tanpa dan Dengan Fitur Seleksi

\begin{tabular}{lcc}
\hline \multicolumn{1}{c}{ Algoritma } & $\begin{array}{c}\text { Tanpa Fitur } \\
\text { Seleksi }\end{array}$ & $\begin{array}{c}\text { Dengan Fitur } \\
\text { Seleksi }\end{array}$ \\
\hline Naive Bayes & $80.06 \%$ & $81.66 \%$ \\
Linear Regression & $79.27 \%$ & $80.70 \%$ \\
Multi Layer & $79.75 \%$ & $82.16 \%$ \\
Perceptron & & \\
\hline
\end{tabular}

Dari implementasi algoritma serta implementasi algoritma dengan fitur seleksi Weight by Information Gain didapatkan hasil perbandingan akurasi yang disajikan pada tabel 7. Tabel 7 menunjukkan perbandingan akurasi dari algoritma Naive Bayes, Linear Regression dan Multi Layer Perceptron tanpa atau dengan fitur seleksi Weight by Information Gain. Hasil yang diperoleh adalah akurasi dengan menggunakan fitur seleksi Weight by Information Gain lebih tinggi daripada tenpa menggunakan fitur seleksi Weight by Information Gain. 
Penerapan algoritma Naive Bayes, Linear Regression, dan Multi Layer Perceptron menghasilkan akurasi yang tergolong baik. Algoritma Naive Bayes menghasilkan akurasi sebesar $80.06 \%$ dengan waktu eksekusi 0,63 detik, algoritma Linear Regression sebesar $79.27 \%$ dengan waktu eksekusi 0,63 detik dan algoritma Multi Layer Perceptron sebesar $79.75 \%$ dengan waktu eksekusi 3 menit 38 detik. Tetapi pada penerapannya, hasil akurasi tersebut masih dapat ditingkatkan dengan menggunakan fitur seleksi dan fitur seleksi yang dipilih pada penelitian ini adalah Weight by Information Gain. Dengan menggunakan fitur seleksi pada algoritma tersebut didapatkan bahwa algoritma Naive Bayes menghasilkan akurasi sebesar $81.66 \%$ dengan waktu eksekusi 1,16 detik, algoritma Linear Regression sebesar $80.70 \%$ dengan waktu eksekusi 2,44 detik dan algoritma Multi Layer Perceptron sebesar $82.16 \%$ dengan waktu eksekusi 1 jam 57 menit.

\section{Kesimpulan}

Dari hasil penelitian, disimpulkan bahwa penerapan fitur seleksi Weight by Information Gain pada algoritma Naive Bayes, Linear Regression, dan Multi Layer Perceptron menghasilkan peningkatan akurasi meskipun tidak terlalu signifikan dan waktu eksekusi yang tidak terpaut jauh jika menggunakan ataupun tanpa fitur seleksi kecuali Multi Layer Perceptron yang membutuhkan waktu lebih lama dalam proses eksekusi. Kesimpulan lain dari penelitian ini adalah algoritma Naive Bayes dengan menggunakan dataset mahasiswa dalam kasus prediksi kelulusan lebih unggul tingkat akurasinya dibanding dengan menggunakan algoritma Linear Regression dan Multi Layer Perceptron serta akurasi Multi Layer Perceptron lebih tinggi dibanding Linear Regression meskipun waktu eksekusi yang dibutuhkan terhitung lama jika tanpa fitur seleksi Weight by Information Gain. Sedangkan jika menggunakan fitur seleksi Weight by Information Gain, algoritma Multi Layer Perceptron lebih unggul hasil akurasinya dibanding algoritma Naive Bayes dan Linear Regression tetapi meskipun lebih unggul hasil akurasinya, waktu eksekusi yang dibutuhkan tergolong lama sehingga algoritma tersebut belum layak dikatakan optimal karena menurut beberapa penelitian, algoritma yang optimal yaitu algoritma dengan akurasi baik dan waktu eksekusi yang singkat.

Untuk penelitian penerapan algoritma pada pemodelan prediksi kelulusan mahasiswa kedepannya dapat menggunakan algoritma lain selain algoritma Naive Bayes, Linear Regression, dan Multi Layer Perceptron. Selain itu dapat pula menggunakan fitur seleksi maupun algoritma optimasi lainnya untuk meningkatkan hasil akurasi agar dapat lebih optimal. Penelitian ini juga dapat dikembangkan di bidang lain selain bidang pendidikan misalnya perbankan, kedokteran, dan lain-lain.

\section{Daftar Pustaka}

[1] M. Pendidikan, D. A. N. Kebudayaan, and R. Indonesia, "Peraturan Menteri Pendidikan Dan Kebudayaan Nomor 03 Tahun 2020 Tentang Standar Nasional Perguruan Tinggi," 2020.
[2] D. Xhemali, C. J. Hinde, and R. G. Stone, "Naive Bayes vs. Decision Trees vs. Neural Networks in the Classification of Training Web Pages," Int. J. Comput. Sci., vol. 4, no. 1, pp. 16-23, 2009, [Online]. Available: http://cogprints.org/6708/.

[3] P. M. Barnaghi, V. A. Sahzabi, and A. A. Bakar, "A Comparative Study for Various Methods of Classification," Int. Conf. Inf. Comput. Networks, vol. 27, no. Icicn, pp. 6266, 2012.

[4] P. M. Arsad, N. Buniyamin, and J. A. Manan, "A neural network students' performance prediction model (NNSPPM)," Smart Instrumentation, Meas. Appl. (ICSIMA), 2013 IEEE Int. Conf., no. November, pp. 1-5, 2013, doi: 10.1109/ICSIMA.2013.6717966.

[5] P. M. Arsad, N. Buniyamin, and J. L. A. Manan, "Prediction of engineering students' academic performance using artificial neural network and linear regression: A comparison," 2013 IEEE 5th Int. Conf. Eng. Educ. Aligning Eng. Educ. with Ind. Needs Nation Dev. ICEED 2013, pp. 43-48, 2014, doi: 10.1109/ICEED.2013.6908300.

[6] P. Mohd Arsad, N. Buniyamin, and J. L. Ab Manan, "Neural Network and Linear Regression methods for prediction of students' academic achievement," IEEE Glob. Eng. Educ. Conf. EDUCON, no. April, pp. 916-921, 2014, doi: 10.1109/EDUCON.2014.6826206.

[7] M. Ben, E. Houari, O. Zegaoui, and A. Abdallaoui, "Prediction of Air Temperature using Multi-Layer Perceptrons with Levenberg-Marquardt Training Algorithm," Int. Res. J. Eng. Technol., vol. 02, no. 08, pp. 2395-56, 2015.

[8] A. Jananto, "Algoritma Naive Bayes untuk Mencari Perkiraan Waktu Studi Mahasiswa," Teknol. Inf. Din., vol. 18, no. 1, pp. 9-16, 2013.

[9] M. Ridwan, H. Suyono, and M. Sarosa, "Penerapan Data Mining Untuk Evaluasi Kinerja Akademik Mahasiswa Menggunakan Algoritma Naive Bayes Classifier," Eeccis, vol. 7, no. 1, pp. 59-64, 2013.

[10] S. Budi, Data Mining Teknik Pemanfaatan Data untuk Keperluan Bisnis. 2007.

[11] H. Goker, H. I. Bulbul, and E. Irmak, "The Estimation of Students' Academic Success by Data Mining Methods," 2013 12th Int. Conf. Mach. Learn. Appl., vol. 2, pp. 535539, 2013, doi: 10.1109/ICMLA.2013.173.

[12] D. Echegaray-Calderon, O A. Barrios-Aranibar, "Optimal selection of factors using Genetic Algorithms and Neural Networks for the prediction of students' academic performance," 2015 Lat. Am. Congr. Comput. Intell., pp. 16, 2015, doi: 10.1109/LA-CCI.2015.7435976.

[13] B. Rahmani and H. Aprilianto, "Early Model of Student's Graduation Prediction Based on Neural Network," TELKOMNIKA (Telecommunication Comput. Electron. Control., vol. 12, no. 2, p. 465, 2014, doi: 10.12928/TELKOMNIKA.v12i2.1603.

[14] S. Chormunge and S. Jena, "Efficient feature subset selection algorithm for high dimensional data," Int. J. Electr. Comput. Eng., vol. 6, no. 4, pp. 1880-1888, 2016, doi: 10.11591/ijece.v6i4.9800.

[15] A. A. Syafitri Hidayatul AA, Yuita Arum S, "Seleksi Fitur Information Gain untuk Klasifikasi Penyakit Jantung Menggunakan Kombinasi Metode K-Nearest Neighbor dan Naïve Bayes," J. Pengemb. Teknol. Inf. dan Ilmu Komput., vol. 2, no. 9, pp. 2546-2554, 2018.

[16] F. Gorunescu, "Data mining: Concepts, models and techniques," Intell. Syst. Ref. Libr., 2011, doi: 10.1007/9783-642-19721-5. 